\title{
Prediksi Rerata Harga Beras Tingkat Grosir Indonesia dengan Long Short Term Memory
}

\author{
Fadil Indra Sanjaya*1, Dadang Heksaputra ${ }^{2}$ \\ ${ }^{1}$ Fakultas Teknologi Informasi dan Elektro, Universitas Teknologi Yogyakarta, Yogyakarta \\ ${ }^{2}$ Fakultas Komputer, Universitas Alma Ata, Yogyakarta \\ e-mail:*fadil.indra@staff.uty.ac.id, ${ }^{2}$ dadang@almaata.ac.id
}

\begin{abstract}
Abstrak
Fluktuasi harga bahan pokok khususnya harga beras yang tidak terkendali berimbas pada kerugian bagi produsen dan konsumen. Untuk dapat menjembatani permasalahan tersebut maka dibutuhkan pengambilan keputusan yang tepat. Prediksi adalah salah satu unsur yang dapat digunakan dalam mendukung pengambilan keputusan yang tepat. Prediksi dalam pengambilan keputusan didasarkan pada data yang ada pada waktu sekarang dan waktu lampau sehingga mampu digunakan untuk menggambarkan kondisi yang sesuai dengan sasaran yang ingin dicapai. Dengan prediksi harga beras yang akurat maka diharapkan pengambil keputusan mampu memutuskan kebijakan yang baik atau melakukan tindakan preventif untuk meminimalkan kerugian. Pada studi ini mengkaji prediksi harga beras ditingkat grosir indonesia dengan pendekatan Recurrent Neural Network Long Short Term Memory (RNN LSTM). Dalam studi ini data yang digunakan adalah data Rata-rata Harga Beras di Tingkat Perdagangan Besar/Grosir Indonesia tahun 2010-2020 yang didapat dari badan pusat statistic Indonesia. Hasil yang didapat dari evaluasi hasil prediksi pada epoch 20 hingga 1000 menghasilkan nilai Root Mean Square Error (RMSE) terkecil yaitu 0,43 yang menunjukkan bahwa metode LSTM mampu digunakan untuk memprediksi harga beras di tingkat grosir Indonesia dengan cukup baik. Dan untuk menguji seberapa dekat hubungan antara prediksi dan nilai RMSE maka di lakukan uji keroleasi denga metode pearson. Dari hasil uji korelasi didapatkan nilai $r$ yang positif yang artinya terdapat hubungan yang cukup signifikan antara variabel prediksi dan nilai RMSE.
\end{abstract}

Kata kunci — Long Short Term Memory, RMSE, Prediksi, Harga Beras

\begin{abstract}
Fluctuations in prices of food staples, especially rice price which is uncontrolled, have an impact on losses for producers and consumers. To be able to bridge these problems requires the right decision making. Prediction is one element that can be used in supporting the right decision making. Predictions in decision making are based on existing data in the present and the past so that they can be used to describe conditions that are in line with the objectives to be achieved. With accurate rice price predictions, it is expected that decision makers will be able to decide on good policies or take preventive actions to minimize losses. In this study examines the prediction of rice prices at the Indonesian wholesale level using the Recurrent Neural Network Long Short Term Memory (RNN LSTM) approach. In this study, the data used is the average rice price at the Indonesian Wholesale / Wholesale Trade Year 2010-2020 obtained from the Indonesian statistical center. The results that obtained from the evaluation of prediction's results on epoch 20 to 1000 produce the smallest Root Mean Square Error (RMSE) value of 0.43 which is shows that the LSTM method can be used to predict the price of rice at the Indonesian wholesale level quite well. And to test how close the relationship between prediction and RMSE values is done by the correlation test with the Pearson method. From the
\end{abstract}


correlation test results obtained a positive $r$ value which means that there is a significant relationship between the predictor variable and the RMSE value.

Keywords — Long Short Term Memory, RMSE, prediction, rice price

\section{PENDAHULUAN}

P ada saat ini negara Indonesia dihadapkan pada suatu permasalahan yang cukup pelik yang berimbas pada kesejahterahan warganya yaitu terpenuhinya kebutuhan bahan pokok. Terpenuhinya kebutuhan akan bahan pokok merupakan salah satu hal yang penting dalam kesejahterahan hidup. Ketidak stabilan harga dan kebijakan pemerintah membuat kebutuhan ini terkadang menjadi sulit untuk terpenuhi. Pada dasarnya sebuah harga barang terbentuk karena adanya kekuatan penawaran dan permintaan yang bertemu dalam satu titik [1]. Harga akan turun jika penawaran tinggi sedang permintaan rendah dan harga akan naik jika penawaran rendah sedang permintaan tinggi. Namun, berbeda untuk bahan pokok seperti harga beras dikarenakan sifatnya yang harus terpenuhi bagi kehidupan permintaan akan bahan pokok cenderung stabil (inelastis) terhadap perubahan harga [2]. Inilah yang menyebabkan harga bahan pokok khususnya beras menjadi sangat fluktuatif saat terjadi perubahan penawaran

Dilakukannya studi ini bertujuan untuk melakukan prediksi harga bahan pokok khususnya beras ditingkat grosir Indonesia. Dengan dihasilkannya prediksi yang tepat, maka diharapkan mampu membantu pengambil keputusan dalam hal ini pemerintah dalam menjamin harga bahan pokok khususnya beras tetap terjangkau oleh konsumen dan membuat aturan yang memihak pada kesejahterahan rakyat Indonesia. Selain itu prediksi yang akurat juga mampu dimanfaatkan pedangang grosir dan produsen atau petani dalam menyusun rencana dan strategi dalam menjual produk beras mereka untuk meminimalkan resiko yang akan dihadapi.

Penelitian serupa sebelumnya pernah dilakukan oleh Heksaputra, dkk di tahun 2013 yang bertujuan untuk memprediksi kualitas pertumbuhan tanaman berdasarkan pengaruh iklim dengan menggunakan teorema naïve bayes. Hasil yang didapatkan dari penelitian ini adalah kesimpulan bahwa iklim sangat berpengaruh terhadap prediksi kualitas suatu tanaman dan juga untuk kerja teorema naïve bayes sendiri sudah dapat dikatakan mampu mengakomodasi prediksi kualitas pangan dengan cukup baik.

Penelitian serupa juga pernah dilakukan oleh Mohammad Arif Rasyidi ditahun 2017 yang bertujuan untuk melakukan prediksi harga bahan pokok nasional jangka pendek dengan menggunakan metode ARIMA. Hasil yang didapatkan dari penelitian ini adalah menunjukkan bahwa model ARIMA yang dibangun mampu memprediksi harga bahan pokok dengan cukup akurat.

Teora Metode naïve bayes sendiri memiliki kelebihan yaitu mempu melakukan prediksi dengan data yang kecil dan juga cepat serta efisien sehingga cocok digunakan untuk prediksi harga atau data time series. Namun, tingkat keakuratan dari teorema naïve bayes sangat sulit diukur dikarenakan sifatnya yang subjektif [3]. Untuk itu metode ini tidak cocok untuk prediksi yang hasilnya digunakan sebagai dasar pengambilan keputusan yang krusial.

Disisi lain untuk metode ARIMA sendiri memiliki kelebihan yaitu dapat digunakan untuk semua pola data time series. ARIMA menggunakan nilai pada masa lalu dan masa sekarang dari variabel dependen untuk menghasilkan peramalan jangka pendek yang akurat. Metode ARIMA sebenarnya cocok digunakan untuk prediksi harga, namun hanya untuk jangka pendek dan dalam pengolahan data yang kecil. Sedang, untuk mengakomodasi prediksi dengan pengolahan data yang besar dan untuk jangka panjang, metode ARIMA kurang mampu bekerja secara efektif [4]. Dengan demikian hasil dari metode ARIMA menurut peneliti kurang mampu mengakomodasi pengambilan keputusan yang krusial.

Fadil Indra Sanjaya, et., al (Prediksi Rerata Harga Beras Tingkat Grosir Indonesia dengan Long Short Term Memory) 
Permasalahan harga bahan pokok khususnya harga beras sendiri menjadi perhatian yang cukup penting saat ini, untuk itu dibutuhkan prediksi yang akurat. Prediksi yang baik dan akurat tidak lepas dari peran model prediksi yang baik. Tujuan penelitan ini adalah untuk membuat model yang bisa dikatakan cukup baik dalam melakukan prediksi harga beras ditingkat grosir, sehingga mampu dijadikan dasar pengambilan keputusan. Pada studi ini akan digunakan metode Long Short Term Memory Neural Network (LSTM). LSTM dipilih karena diangkap mampu mengakomodasi permasalahan prediksi harga beras yang dihadapi dikarenakan, LSTM sendiri merupakan salah satu pengembangan neural network, dimana dapat digunakan untuk pemodelan data time series dan mampu melakukan pembelajaran secara terus menerus [5]. LSTM mampu mengatasi ketergantungan jangka panjang (long term dependencies) pada masukannya [6]. LSTM juga mampu diterapkan pada berbagai tugas sekuensial dan bahasa pemodelan. Sebuah cell dalam LSTM menyimpan sebuah nilai atau keadaan (cell state), sehingga baik untuk prediksi jangka panjang atau singkat [7][8]. Hal ini yang menyebabkan LSTM unggul dan cukup untuk dijadikan dasar pengambilan keputusan. Hasil dari studi ini nantinya diharapkan mampu memberikan manfaat untuk mengakomodasi pengambilan keputusan bagi pemerintah atau pengambil keputusan dan juga bagi pedagang dan produsen dalam menyusun strategi kedepan.

\section{METODE PENELITIAN}

Penelitian ini dilakuakn dengan metode kuantitatif dimana peneliti berusaha untuk menguji hubungan antar variabel dan juga peneliti berusaha untuk menguji model yang disusun. Penelitian ini dilakukan melalui beberapa tahapan penelitian dengan proses-proses tertentu. Adapun tahapan-tahapan penelitian yang dilakukan ini dapat dilihat pada gambar 1. Tahapan aktivitas dalam penelitian terbagi menjadi 3 proses besar secara berturut-turut yaitu penyiapan data, pembuatan model, dan evaluasi model.

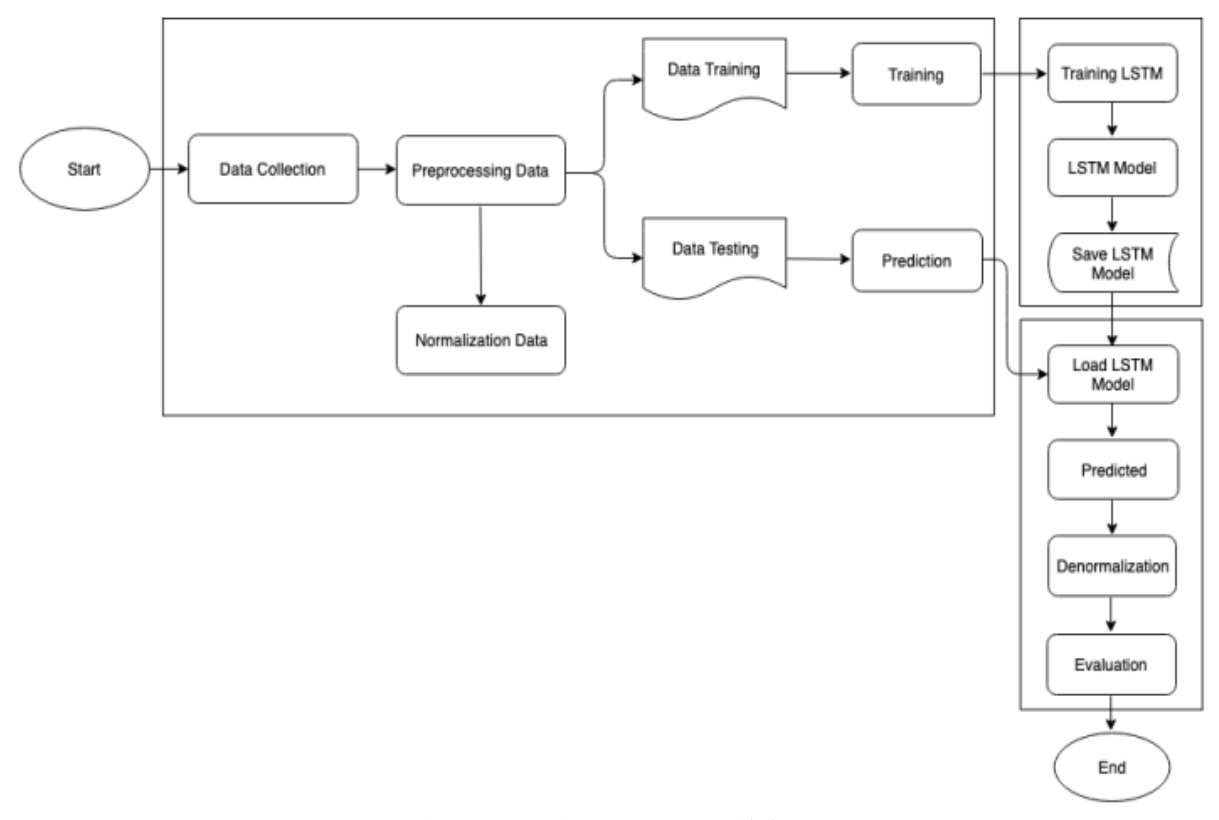

Gambar 1. Tahapan Penelitian [5]

Fadil Indra Sanjaya, et., al (Prediksi Rerata Harga Beras Tingkat Grosir Indonesia dengan Long Short Term 
Tahapan penyiapan data terdiri dari pengumpulan data, preprocessing, representasi data, dan pemilahan data (dataset splitting). Untuk preprocessing data terdiri dari proses data cleansing dan normalisasi dataset. Setelah tahap preprocessing data selesai dilakukan kemudian dataset dibagi menjadi dua, dataset training dan dataset testing. Tahap pembuatan model dimulai dengan pembuatan model dan training LSTM Network. Model yang diperoleh selanjutnya digunakan pada proses prediksi. Tahap akhir eksperimen berupa proses evaluasi model dimana data hasil testing telah dihasilkan kemudian dilakukan proses denormalisasi data untuk mendapatkan nilai hasil prediksi dan nilai evaluasi dari hasil kinerja model.

\subsection{Penyiapan Data}

Tahap ini diawali dengan melakukan pengumpulan data dan kemudian menjadikannya dalam bentuk dataset. Untuk data dalam studi ini sendiri diperoleh dari Badan Pusat Statistik Indonesia. Bentuk dataset berupa data rata-rata harga beras ditingkat perdagangan besar atau grosir Indonesia dalam kurun waktu 10 tahun yaitu tahun 2010-2020. Data kemudian di konversikan dalam bentuk file .csv. Setiap data mengandung dua atribut yaitu tanggal dan harga beras. Adapun beberapa sampel data ditunjukkan pada tabel 1.

Tabel 1. Sampel Dataset Penelitian

\begin{tabular}{|c|c|c|}
\hline No. & Tanggal & Harga Beras (Rupiah/Kg) \\
\hline 1 & Januari (2010) & 6702 \\
\hline 2 & Febuari (2010) & 6888 \\
\hline 3 & Maret (2010) & 6854 \\
\hline 4 & April (2010) & 6761 \\
\hline 5 & Mei (2010) & 6772 \\
\hline
\end{tabular}

Dataset yang dikumpulkan kemudian dipilah menjadi data training dan data testing. Setelah seluruh dataset tersebut dibagi sesuai komposisi lalu dilakukan proses selanjutnya yaitu preprosesing data. Proses preprosesing data pada studi ini adalah dengan melakukan normalisasi pada dataset menggunakan teknik min-max scaler dengan merubah nilai real atau nilai aktual menjadi nilai dengan range interval. Persamaan matematik untuk normalisasi ditunjukkan pada persamaan 1 .

Keterangan:

$$
x^{\prime}=\frac{x-x \min }{x \max -x \min }
$$

x' : Nilai Hasil Normalisasi

x. : Nilai data aktual yang akan dinormalisasi

xmin. : Nilai minimum dari data aktual

xmax : Nilai maximum dari data aktual

\section{2 Pembuatan Model}

Long Short Term Memory (LSTM) disebut juga sebagai jaringan saraf dengan arsitektur yang mudah beradaptasi, sehingga bentuknya dapat disesuaikan, tergantung pada aplikasinya. LSTM merupakan turunan dari metode RNN (Recurrent Neural Network). Recurrent Neural Network merupakan jaringan saraf berulang yang didesain khusus untuk menangani data berurutan (sequence data) [9]. Namun RNN mempunyai masalah vanishing dan exploding gradient yaitu apabila terjadi perubahan pada jangkauan nilai dari satu lapisan menuju lapisan berikutnya pada sebuah arsitektur. LSTM dibangun dan dirancang untuk mengatasi masalah gradien menghilang dari RNN ketika berhadapan dengan vanishing dan

Fadil Indra Sanjaya, et., al (Prediksi Rerata Harga Beras Tingkat Grosir Indonesia dengan Long Short Term 
exploding gradient tersebut [10]. Arsitektur LSTM terdiri dari lapisan input, lapisan output, dan lapisan tersembunyi yang disajikan pada Gambar 2.

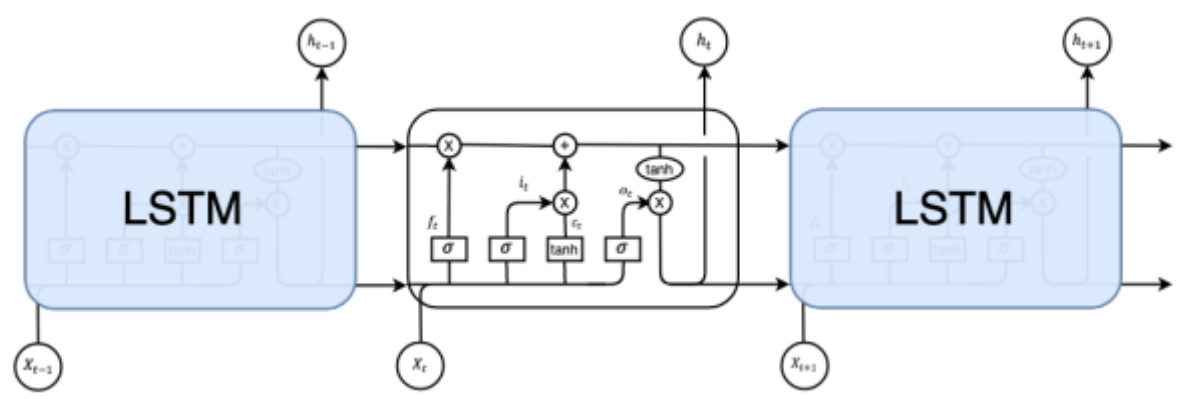

Gambar 2. Arstitektur Long Short Term Memory (LSTM) [5]

Lapisan tersembunyi terdiri dari sel memori, satu sel memori memiliki tiga gate yaitu input gate, forget gate, output gate. Input gate berfungsi mengontrol berapa banyak informasi yang harus disimpan dalam keadaan sel. Ini mencegah sel dari menyimpan data yang tidak perlu. Forget gate berfungsi mengontrol sejauh mana nilai tetap di dalam sel memori. Output Gate berfungsi untuk memutuskan berapa banyak konten atau nilai dalam sel memori, digunakan untuk menghitung output [5].

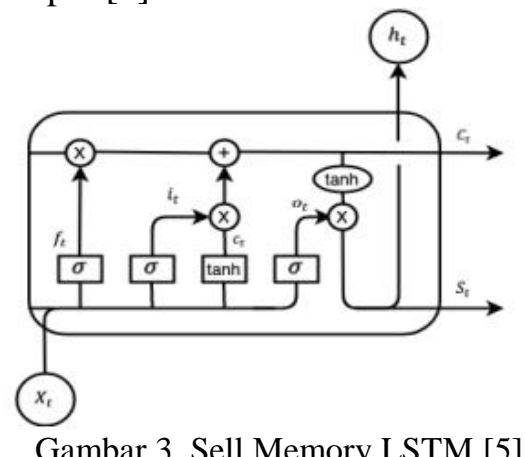

Pada gambar 3 disajikan isi dari lapisan tersembunyi LSTM yaitu sel memori. Sebuah sel memori di LSTM menyimpan sebuah nilai atau keadaan (cell state), baik untuk periode waktu yang panjang atau singkat [11]. Penjelasan untuk gerbang-gerbang yang ada pada satu sel memori Long Short Term Memory (LSTM) adalah sebagai berikut:

\section{Input Gate (it)}

Input gate berperan mengambil output sebelumnya dan input baru serta melewatkan mereka melalui lapisan sigmoid. Gate ini mengembalikan nilai 0 atau 1. Adapun persamaan matematik dari it ditunjukkan pada persamaan 2 .

Keterangan:

$$
i_{t}=\sigma\left(W_{i} S_{t-1}+W_{i} X_{t}\right) \quad \text { (2) [5] }
$$

Wi : Bobot dari input gate

St-1 : State sebelumnya atau state pada waktu t-1

$\mathrm{Xt} \quad$ : Input pada waktu $\mathrm{t}$

$\sigma \quad$ : Fungsi aktivasi sigmoid

Fadil Indra Sanjaya, et., al (Prediksi Rerata Harga Beras Tingkat Grosir Indonesia dengan Long Short Term Memory) 
Nilai gerbang input dikalikan dengan output dari lapisan kandidat $(\tilde{C})$. Adapun persamaan matematik dari $(\tilde{C})$ ditunjukkan pada persamaan 3 .

Keterangan:

$$
\mathrm{C}=\tanh \left(W_{c} S_{t-1}+W_{c} X_{t}\right)
$$

$\tilde{C} \quad:$ Intermediate cell state

Wc : Bobot dari cell state.

St-1 : State sebelumnya atau state pada waktu t-1

$\mathrm{Xt} \quad$ : Input pada waktu $\mathrm{t}$

\section{Forget Gate $(f t)$}

Forget gate adalah lapisan sigmoid yang mengambil output pada waktu $\mathrm{t}-1$ dan input pada waktu $\mathrm{t}$ dan menggabungkannya serta menerapkan fungsi aktivasi sigmoid. Karena sigmoid, output dari gate ini adalah 0 atau 1. Jika $f t=0$ maka keadaan (state) sebelumnya akan dilupakan, sementara jika $f t=1$ state sebelumnya tidak berubah. Adapun persamaan matematik dari $f t$ ditunjukkan pada persamaan 4.

Keterangan:

$$
f_{t}=\sigma\left(W_{f} S_{t-1}+W_{f} X_{t}\right) \quad \text { (4) }[5]
$$

Wf : Bobot dari input gate

St-1 : State sebelumnya atau state pada waktu t-1

$\mathrm{Xt} \quad$ : Input pada waktu $\mathrm{t}$

$\sigma \quad$ : Fungsi aktivasi sigmoid

\section{Ouput Gate (ot)}

Output gate mengontrol seberapa banyak state yang lewat ke output dan bekerja dengan cara yang sama dengan gate lainnya. Dan terakhir menghasilkan cell state yang baru $(h t)$. Persamaan matematik dari ot ditunjukkan pada persamaan 5 dan untuk $h t$ ditunjukkan pada persamaan 6.

Keterangan:

$$
\begin{gathered}
O_{t}=\sigma\left(W_{o} S_{t-1}+W_{o} X_{t}\right) \\
h_{t}=O_{t} * \tanh (c t)
\end{gathered}
$$

Wo : Bobot dari input gate

St-1 : State sebelumnya atau state pada waktu t-1

$\mathrm{Xt} \quad$ : Input pada waktu $\mathrm{t}$

$\sigma \quad$ : Fungsi aktivasi sigmoid

Untuk akurasi hasil prediksi diperoleh dari data yang sudah dilatih berdasarkan dari jumlah lapisan tersembunyi (hidden layer).

\section{3. Proses Evaluasi Model}

Setelah model dibuat maka model yang dihasilkan kemudian di load untuk kemudian digunakan pada tahapan selanjutnya yaitu diantaranya:

\section{3.1. Proses Denormalisasi}

Setelah mendapatkan hasil prediksi dari proses prediksi, maka sebelum menghitung akurasi hasil prediksi harus dilakukan denormalisasi yaitu data diubah menjadi nilai real kembali [12]. Karena data hasil prediksi masih berupa data berbentuk range interval yang dilakukan pada normalisasi data. Adapun tujuan dilakukan denormalisasi adalah agar output

Fadil Indra Sanjaya, et., al (Prediksi Rerata Harga Beras Tingkat Grosir Indonesia dengan Long Short Term 
mudah dibaca dan mudah dimengerti. Untuk persamaan matematik denormalisasi ditunjukkan pada persamaan 7 .

Keterangan:

$$
d=d^{\prime(\max -\min )}+\min \quad \text { (7) [5] }
$$

d : Nilai hasil denormalisasi

d' : Nilai data normalisasi

max : Nilai maksimum dari data aktual

min : Nilai minimum dari data actual

\section{3.2. Proses Evaluasi}

Untuk proses evaluasi kinerja model pada penelitian ini digunakan metode Root Mean Square Error (RMSE). Root Mean Square Error (RMSE) sendiri yaitu metode alternatif untuk mengevaluasi teknik peramalan yang digunakan untuk mengukur tingkat akurasi hasil perkiraan suatu model. Nilai yang dihasilkan RMSE merupakan nilai rata-rata kuadrat dari jumlah kesalahan pada model prediksi. Root Mean Square Error (RMSE) merupakan teknik yang mudah diimplementasikan dan telah banyak digunakan dalam berbagai studi yang berkaitan dengan prediksi atau peramalan [12] [13]. Untuk persamaan matematik Root Mean Square Error (RMSE) ditunjukkan pada persamaan 8.

$$
\sqrt{\frac{1}{n}} \sum_{i}^{n}\left(\tilde{y}_{i}-y_{i}\right)^{2} \quad \text { (8) [5] }
$$

Keterangan:

$\tilde{y} i \quad$ : Nilai hasil peramalan

$y i \quad$ : Nilai aktual / Nilai sebenarnya

n : Jumlah data

\section{HASIL DAN PEMBAHASAN}

Dari hasil eksperimen yang dilakukan terhadap dataset rata-rata harga beras ditingkat grosir indonesia dengan jumlah 1000 iterasi atau epoch, kemudian dihasilkan keluaran yang ditunjukkan pada tabel dan gambar sebagai berikut:

Tabel 2. Hasil Nilai Prediksi dan Nilai Aktual Eksperimen dengan epoch 1000

\begin{tabular}{|c|c|c|}
\hline Bulan (tahun 2021) & Prediksi & Ekspetasi \\
\hline Januari & 12177.036052 & 12211.000000 \\
\hline Febuari & 12305.661473 & 12222.000000 \\
\hline Maret & 12234.092403 & 12124.000000 \\
\hline April & 12104.740333 & 12019.000000 \\
\hline Mei & 11991.839519 & 12008.000000 \\
\hline Juni & 12041.849842 & 12009.000000 \\
\hline Juli & 12034.066184 & 12021.000000 \\
\hline Agustus & 12062.921991 & 12018.000000 \\
\hline September & 12045.640933 & 12050.000000 \\
\hline Oktober & 12105.869146 & 12108.000000 \\
\hline November & 12172.820497 & 12120.000000 \\
\hline Desember & 12149.844028 & 12183.000000 \\
\hline
\end{tabular}

Fadil Indra Sanjaya, et., al (Prediksi Rerata Harga Beras Tingkat Grosir Indonesia dengan Long Short Term Memory) 
Selanjutnya dilakukan korelasi dari hasil keluaran sesuai dengan beberapa epoch yang sudah di tentukan yang ditunjukkan pada tabel 3. Korelasi merupakan hubungan antar variabel. Analisis korelasi berfungsi untuk melihat seberapa kuat hubungan antar variabel dan bagaimana arahnya. Arah hubungan ditunjukkan dengan hubungan positif atau negatif. Dari tabel 3 dapat diketahui bahwa nilai RMSE terkecil ditemukan pada kombinasi data epoch 700. Nilai RMSE terkecil ditemukan pada kombinasi data epoch 540. Pada gambar 4 dan gambar 5 menunjukan adanya gap antara prediksi dan ekspektasi.

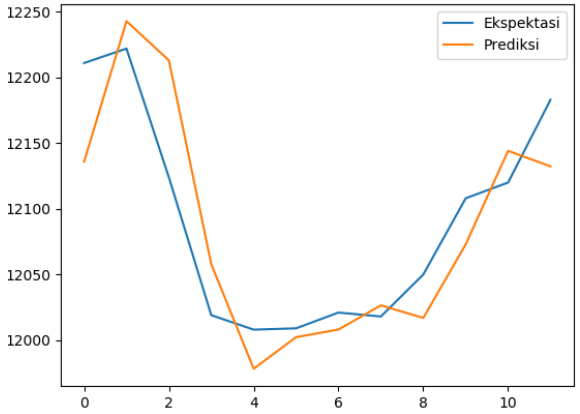

Gambar 4. Hasil Epoch 700 RMSE terkecil

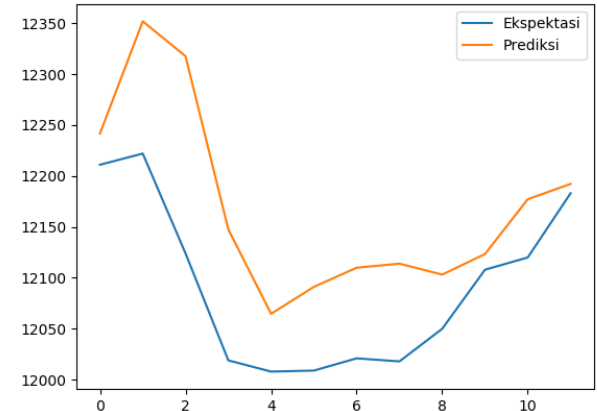

Gambar 5. Hasil Epoch 540 RMSE terbesar

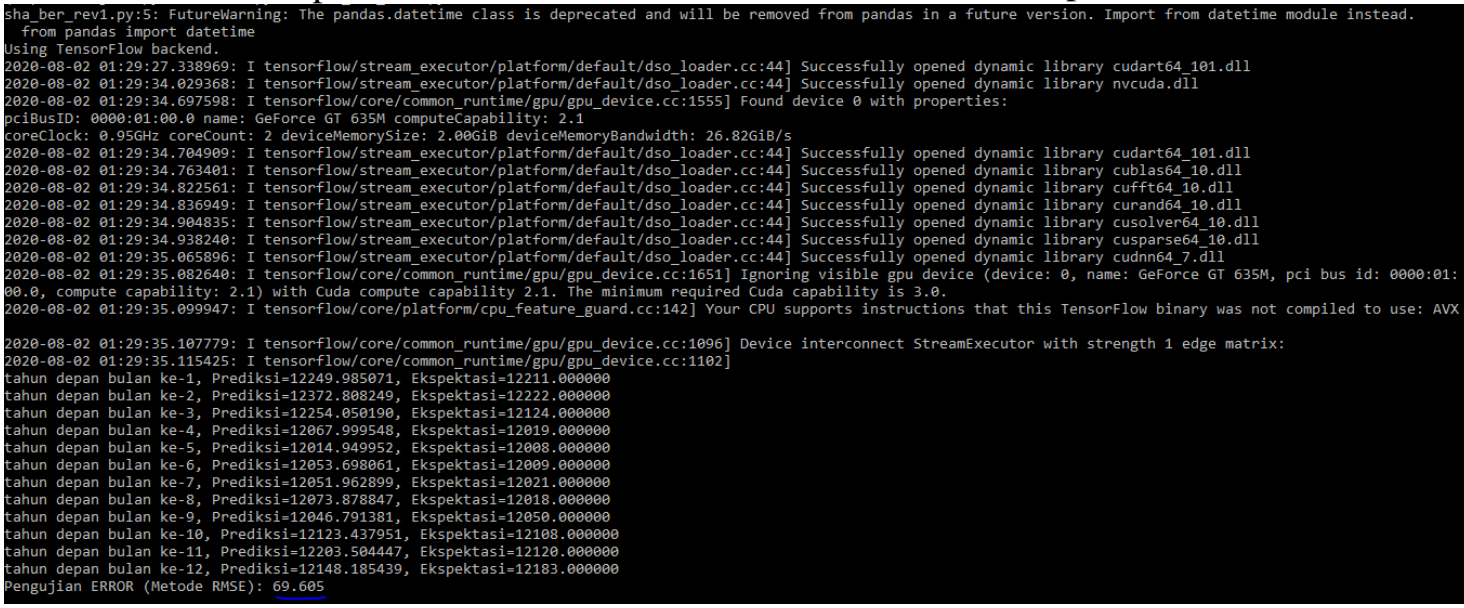

Gambar 6. Output Aplikasi Perhitungan Root Mean Square Error

Gambar 6 menunjukan output perhitungan dalam menampilkan root mean square error. Hasil perhitungan menghitung error dari nilai prediksi dengan ekspektasi. Nilai prediksi dihitung dengan Long Short Term Memory. Nilai ekspektasi diperoleh dari data konversi perhitungan data supervised learning time series dengan cara mentrasformasikan data tersebut.

Tabel 3. Hasil Korelasi Prediksi dengan Root Mean Squared Error

\begin{tabular}{|c|c|c|}
\hline No & Epoch & $\begin{array}{c}\text { Pengujian } \\
\text { ERROR } \\
\text { (Metode } \\
\text { RMSE) }\end{array}$ \\
\hline 1 & 20 & 59.516 \\
\hline 2 & 40 & 66.866 \\
\hline
\end{tabular}

\begin{tabular}{|c|c|c|}
3 & 60 & 60.159 \\
\hline 4 & 80 & 57.462 \\
\hline 5 & 100 & 60.17 \\
\hline 6 & 120 & 58.497 \\
\hline 7 & 140 & 59.673 \\
\hline 8 & 160 & 53.634 \\
\hline
\end{tabular}

Fadil Indra Sanjaya, et., al (Prediksi Rerata Harga Beras Tingkat Grosir Indonesia dengan Long Short Term Memory) 


\begin{tabular}{|c|c|c|}
9 & 180 & 57.488 \\
\hline 10 & 200 & 59.251 \\
\hline 11 & 220 & 53.581 \\
\hline 12 & 240 & 60.169 \\
\hline 13 & 260 & 53.181 \\
\hline 14 & 280 & 59.798 \\
\hline 15 & 300 & 57.295 \\
\hline 16 & 320 & 53.235 \\
\hline 17 & 340 & 69.208 \\
\hline 18 & 360 & 61.222 \\
\hline 19 & 380 & 55.991 \\
\hline 20 & 400 & 50.903 \\
\hline 21 & 420 & 55.889 \\
\hline 22 & 440 & 51.846 \\
\hline 23 & 460 & 51.143 \\
\hline 24 & 480 & 61.99 \\
\hline 25 & 500 & 58.182 \\
\hline 26 & 520 & 62.455 \\
\hline 27 & 540 & 93.668 \\
\hline 28 & 560 & 51.033 \\
\hline 29 & 580 & 63.767 \\
\hline
\end{tabular}

\begin{tabular}{|c|c|c|}
30 & 600 & 62.642 \\
\hline 31 & 620 & 63.434 \\
\hline 32 & 640 & 56.546 \\
\hline 33 & 660 & 55.628 \\
\hline 34 & 680 & 55.536 \\
\hline 35 & 700 & 42.983 \\
\hline 36 & 720 & 60.875 \\
\hline 37 & 740 & 57.831 \\
\hline 38 & 760 & 52.07 \\
\hline 39 & 780 & 51.637 \\
\hline 40 & 800 & 48.946 \\
\hline 41 & 820 & 53.184 \\
\hline 42 & 840 & 92.704 \\
\hline 43 & 860 & 65.663 \\
\hline 44 & 880 & 60.136 \\
\hline 45 & 900 & 59.081 \\
\hline 46 & 920 & 60.094 \\
\hline 47 & 940 & 82.665 \\
\hline 48 & 960 & 54.715 \\
\hline 49 & 980 & 63.811 \\
\hline 50 & 1000 & 59.315 \\
\hline & & \\
\hline
\end{tabular}

Uji korelasi dapat dilakukan dengan beberapa cara, salah satu yang paling populer adalah dengan korelasi Pearson [14]. Korelasi akan menghasilkan nilai signifikan (2-tailed) antara prediksi bulan pertama, prediksi bulan kedua, hingga bulan keduabelas dari epoch 20 dengan kelipatannya sebesar 20 hingga epoch 1000 yang ditunjukkan pada tabel 4 .

Tabel 4. Hasil Korelasi Prediksi dengan Root Mean Squared Error

\begin{tabular}{|c|c|c|c|}
\hline No & Tahun Pertama & Metode Analisis & $\begin{array}{c}\text { Root Mean Squared } \\
\text { Error (RMSE) }\end{array}$ \\
\hline \multirow{2}{*}{1} & \multirow{2}{*}{ Prediksi bulan pertama } & Pearson Correlation & +0.514 \\
\hline & & Sig. (2-tailed) & 0.000 \\
\hline \multirow{2}{*}{2} & \multirow{2}{*}{ Prediksi bulan kedua } & Pearson Correlation & +0.481 \\
\hline & & Sig. (2-tailed) & 0.000 \\
\hline \multirow{2}{*}{3} & \multirow{2}{*}{ Prediksi bulan ketiga } & Pearson Correlation & +0.836 \\
\hline & & Sig. (2-tailed) & 0.000 \\
\hline \multirow{2}{*}{4} & \multirow{2}{*}{ Prediksi bulan kempat } & Pearson Correlation & +0.723 \\
\hline & & Sig. (2-tailed) & 0.000 \\
\hline \multirow{2}{*}{5} & \multirow{2}{*}{ Prediksi bulan kelima } & Pearson Correlation & +0.547 \\
\hline & & Sig. (2-tailed) & 0.000 \\
\hline \multirow{2}{*}{6} & \multirow{2}{*}{ Prediksi bulan keenam } & Pearson Correlation & +0.372 \\
\hline & & Sig. (2-tailed) & 0.008 \\
\hline
\end{tabular}

Fadil Indra Sanjaya, et., al (Prediksi Rerata Harga Beras Tingkat Grosir Indonesia dengan Long Short Term Memory) 


\begin{tabular}{|c|c|c|c|}
\hline \multirow{2}{*}{7} & \multirow{2}{*}{ Prediksi bulan ketujuh } & Pearson Correlation & +0.658 \\
\hline & & Sig. (2-tailed) & 0.000 \\
\hline \multirow{2}{*}{8} & \multirow{2}{*}{ Prediksi bulan kedelapan } & Pearson Correlation & +0.669 \\
\hline & & Sig. (2-tailed) & 0.000 \\
\hline \multirow{2}{*}{9} & \multirow{2}{*}{ Prediksi bulan kesembilan } & Pearson Correlation & +0.712 \\
\hline & & Sig. (2-tailed) & 0.000 \\
\hline \multirow{2}{*}{10} & \multirow{2}{*}{ Prediksi bulan kesepuluh } & Pearson Correlation & +0.348 \\
\hline & & Sig. (2-tailed) & 0.013 \\
\hline \multirow{2}{*}{11} & \multirow{2}{*}{ Prediksi bulan kesebelas } & Pearson Correlation & +0.354 \\
\hline & & Sig. (2-tailed) & 0.012 \\
\hline \multirow{2}{*}{12} & \multirow{2}{*}{ Prediksi bulan keduabelas } & Pearson Correlation & +0.768 \\
\hline & & Sig. (2-tailed) & 0.000 \\
\hline \multirow{2}{*}{13} & \multirow{2}{*}{ root mean squared error (rmse) } & Pearson Correlation & +1 \\
\hline & & Sig. (2-tailed) & \\
\hline
\end{tabular}

Hasil koefisien korelasi yang dilakukan menunjukkan nilai $\mathrm{r}$ hitung atau pearson correlations dalam analisis bernilai positif maka terdapat hubungan signifikan antara variable prediksi dan nilai RMSE yang artinya jika terjadi peningkatan prediksi akan berimbas pada meningkatnya pula nilai RMSE. Besar koefisien korelasi dengan batasan range dari -1 sampai dengan +1 . Tanda $(+)$ positif ataupun (-) negative terdapat di depan angka koefisien korelasi merupakan petunjuk. Petunjuk bahwa korelasi tersebut merupakan korelasi posittif atau korelasi negative.

\section{KESIMPULAN}

Dari hasil dari penelitian ini telah dihasilkan model prediksi dengan metode LSTM neural network yang dapat digunakan cukup baik untuk memprediksi harga beras untuk tahun berikutnya. Pengujian model dilakukan dengan menggunakan percobaan pencarian model terbaik dari epoch dengan nilai root mean squared error (RMSE) terkecil sehingga didapatkan kesimpulan bahwa antara ekspektasi dan prediksi tidak memiliki gap yang jauh, yang artinya tingkat keakuratan cukup tinggi. Untuk menguji seberapa erat hubungan variabel penelitian dilakukan uji korelasi dengan metode korelasi pearson dan didapatkan kesimpulan bahwa variabel prediksi dan nilai RMSE saling memiliki korelasi signifikan, sehingga diketahui bahwa model yang telah dibangun sudah cukup bagus untuk melakukan prediksi terhadap harga beras dan hasil prediksi bisa digunakan untuk dasar dalam pengambilan keputusan.

\section{SARAN}

Peneliti menyadari bahwa tentunya ada keterbatasan dalam penelitian ini khusunya untuk menentukan metode prediksi apa yang paling tepat sesuai kasus yang dihadapi. Dengan demikian diharapkan untuk penelitian dimasa mendatang dapat dilakukan studi dalam melihat perbandingan performa metode LSTM dengan metode yang lainnya pada neural network dalam hal prediksi, khususnya untuk prediksi harga beras. 


\section{UCAPAN TERIMA KASIH}

Penulis mengucapkan terima kasih kepada Badan Pusat Statistik Indonesia yang telah memberi dukungan berupa data penelitian, sehingga penelitian ini dapat dilakukan dengan baik hingga didapatkan hasil yang ingin dicapai oleh peneliti.

\section{DAFTAR PUSTAKA}

[1] M. A. Rasyidi, 2017, "Prediksi Harga Bahan Pokok Nasional Jangka Pendek Menggunakan ARIMA", JISEBI (Journal of Information Systems Engineering and Business Intelligence), Vol 3, hal 107.

[2] C. Sugiyanto, 2006, "Permintaan Beras Di Indonesia: Revisited", JIEB (Jurnal Ekonomi dan Bisnis Indonesia), Vol 21, hal 138-155.

[3] D. Berrar, 2018, Bayes’ Theorem And Naive Bayes Classifier.

[4] R. Adhikari K. and A. R.K., 2013, An Introductory Study On Time Series Modeling And Forecasting Ratnadip Adhikari R. K. Agrawal.

[5] L. Wiranda, M. Sadikin, J. T. Informatika, and F. I. Komputer, 2019, "Penerapan Long Short Term Memory Pada Data Time Series Untuk Memprediksi Penjualan Produk Pt. Metiska Farma", JANAPATI (Jurnal Nasional Pendidikan Teknik Informatika), Vol XX, hal 1-13.

[6] Y. Hu, J. Ni, and L. Wen, 2020, "A Hybrid Deep Learning Approach By Integrating LSTM-ANN Networks With GARCH Model For Copper Price Volatility Prediction", Elsevier B.V.

[7] K. M. Sabu and T. K. M. Kumar, 2020,"Predictive Analytics In Agriculture: Forecasting Prices Of Arecanuts In Kerala", Vol 171, hal 699-708, Elsevier B.V.

[8] R. C. Staudemeyer and E. R. Morris, 2019, "Understanding LSTM -- A Tutorial Into Long Short-Term Memory Recurrent Neural Networks".

[9] A. A. Rizal and S. Hartati, 2017, "Prediksi Kunjungan Wisatawan Dengan Recurrent Neural Network Extended Kalman Filter", JIK (Jurnal Ilmu Komputer), Vol X, hal 7-18.

[10] A. Yadav, C. K. Jha, and A. Sharan, 2020, "Optimizing LSTM For Time Series Prediction In Indian Stock Market", Vol 167, hal 2091-2100, Elsevier B.V.

[11] X. Qing and Y. Niu, 2018, "Hourly Day-Ahead Solar Irradiance Prediction Using Weather Forecasts By LSTM", Vol 148, hal 461-468, Elsevier Ltd.

[12] A. A. Rizal and S. Soraya, 2018, "Multi Time Steps Prediction Dengan Recurrent Neural Network", MATRIK (Jurnal Manajemen, Teknik Informatika \& Rekayasa Komputer), Vol 18, hal 115-124. 
[13] T. Chai and R. R. Draxler, 2014, "Root Mean Square Error (RMSE) Or Mean Absolute Error (MAE)? -Arguments Against Avoiding RMSE In The Literature", Vol 7.

[14] R. Kurniawan, "Korelasi Linear Pearson Dengan STATCAL, SPSS, Minitab \& R". 